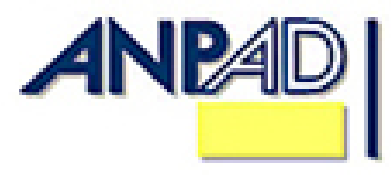

Available online at

http://www.anpad.org.br/bar

BAR, Rio de Janeiro, v. 12, n. 1, art. 6, pp. 109-128, Jan./Mar. 2015

http://dx.doi.org/10.1590/1807-7692bar2015140038

\title{
Drivers of Environmental Management in the Brazilian Context
}

Patricia Calicchio Berardi

Escola Superior de Propaganda e Marketing - ESPM

Renata Peregrino de Brito OneAdvisory

Received 25 June 2014; received in revised form 18 February 2015 (this paper has been with the authors for two revisions); accepted 20 February 2015; published online 17 March 2015. Editor's note. Ivan Montiel served as Action Editor for this article. 


\begin{abstract}
The demand for improved environmental practices inside firms has increased around the world. However, in the process of implementation of environmental management, policy may be decoupled from practice, generating doubts about its effectiveness. This study investigates an overlooked middle step in the environmental management process, analyzing the strength of the main environmental drivers in improving environmental practices inside firms. We developed a set of hypotheses about the influence regulation, voluntary norms and stakeholder pressure have upon environmental management practices, considering the institutional context and different enforcement of these drivers. We use a cross-sectional survey of 150 Brazilian firms to gather information about environmental management and test our hypotheses in a Structural Equation Model. The findings confirm the importance of command and control instruments as well as stakeholder pressure in promoting better environmental practices inside firms. Yet, the results demonstrate that voluntary norms did not influence management practices even though they were perceived as a market opportunity.
\end{abstract}

Key words: environmental management; environmental regulation; voluntary norms; stakeholders; emerging economies. 


\section{Introduction}

Environmental demands are a fact for firms in most institutional contexts (Child \& Tsai, 2005). Drivers of environmental behavior come from constituents inside and outside the firm and exert pressure towards the reduction of negative externalities (Aravind \& Christmann, 2011; Delmas \& Toffel, 2008). These drivers are contingent on their context and may result in different impacts on firms' environmental management practices (Delmas \& Toffel, 2008; López-Gamero, Molina-Azorín, \& Claver-Cortés, 2010). That is, environmental drivers are not equally effective in promoting changes in firms' management practices.

An important issue regards institutional context influence upon business management (Hoskisson, Eden, Lau, \& Wright, 2000). Emerging economies exhibit institutional voids, such as weaker institutions and enforcement of rules, which increase uncertainty levels and promote opportunistic behavior among players (Peng, 2002; Wright, Filatotchev, Hoskisson, \& Peng, 2005). Regarding environmental performance, emerging economies are more tolerant in terms of polluting activities and present exploitative behavior towards the natural environment (Child \& Tsai, 2005; Hoskisson, Wright, Filatotchev, \& Peng, 2013). Although economic expansion has intensified the pressure on the natural environment, there are few studies about environmental management in emerging economies (Aravind \& Christmann, 2011; Child \& Tsai, 2005; Gavronski, Paiva, Teixeira, $\&$ Andrade, 2012).

Even inside the same institutional context, firm response level to environmental demands is not homogeneous (Buysse \& Verbeke, 2003; Crilly, Zollo, \& Hansen, 2012). Among the important drivers, governmental entities, competitors, customers, local communities and employees exert influence on management decisions (Bansal \& Roth, 2000; Christmann, 2004; Clarkson, Li, Richardson, \& Vasvari, 2011). In response to these demands, firms are supposed to adopt environmental measures and reduce environmental impacts. However, inside a firm's operations, the central issue regards the capacity to implement environmental practices and increase competitiveness. In this process, there is no guarantee that external expectations and internal practices will converge (Crilly et al., 2012).

In the interaction between firm and society, the effectiveness of each environmental driver depends on its power in ensuring that changes will take place. However, environmental policy can be decoupled from the implementation of practices and external drivers have limited capacity to control operations inside firms (Crilly et al., 2012; J. W. Meyer \& Rowan, 1977). This implies that firms can superficially address environmental demands in search for legitimacy and not effectively change their practices (Aravind \& Christmann, 2011). While there is a substantial body of literature concerning competitiveness of environmental policies, implementation of environmental practices is frequently taken for granted (Clarkson et al., 2011; Dowell, Hart, \& Yeung, 2000; Jabbour, Silva, Paiva, \& Almada Santos, 2012).

Therefore the objective of this study is to investigate this overlooked middle step in the environmental management process. We study the influence of main external drivers, governmental regulation, voluntary norms and stakeholder pressure in influencing Brazilian firms' environmental practices. Our main contribution constitutes by testing the effectiveness of these drivers in promoting changes inside firms' operations. The relevance of this test is twofold. Theoretically, the investigation of environmental driver effectiveness is important considering that firms may keep their operations unchanged, and do not internalize environmental management costs, while gaining legitimacy and competitiveness. Empirically, debate in the context of institutional voids reveals that environmental drivers have distinct enforcement capacity in changing environmental behavior.

For that purpose, we conducted a survey with environmental managers of 150 medium and large Brazilian manufacturing firms, and tested our hypothesis using a Structural Equation Model. We discuss the findings in light of the existing studies about environmental management and the implications for academic and managerial purposes. This article starts by presenting the particularities 
of the emerging economies' context, the implications on environmental management practices and the hypothesized influence of environmental drivers.

\section{Emerging Economy Context}

Emerging economies are known for a fast-paced economic development, combined with a changing institutional context (Hoskisson et al., 2000). The institutional framework, as the set of formal rules and informal regulations, has the power to reduce uncertainty and provide structure for business development (North, 1990). From the institutional economics perspective, the interaction between firms and institutions can result in market imperfections, such as transaction costs, affecting economic activity (Hoskisson et al., 2000). Institutional theory emphasizes the role institutions have in framing managerial decisions and firm behavior in searching for legitimacy (DiMaggio \& Powell, 1983). Overall, the institutional context provides strong guidance for managerial decisions.

Under the institutional framework, formal and informal constraints interact, signaling acceptable choices for firms. In situations where formal constraints fail, informal constraints come into play to reduce uncertainty (Peng, 2002). In terms of formal rules, governmental regulation and incentives characterize the role institutions have in the management of firms (Hoskisson et al., 2013). Additionally, informal regulations such as professional organizations, accreditation bodies, as well as non-governmental organizations also offer normative guidelines for managerial practices (Child \& Tsai, 2005). Finally, market pressure from clients, suppliers and competitors help shape practices inside firms (Delmas \& Toffel, 2004).

The existence of institutional voids in the context of emerging economies exerts strong influence over business strategy and firm performance (Carney, Gedajlovic, Heugens, Van Essen, \& Van Oosterhout, 2011; Goldszmidt, Brito, \& Vasconcelos, 2011). One of the characteristics of institutional voids is that they provide a context of low embeddedness and weak enforcement of rules (Rodrigues, 2013). This latter aspect has strong influence over firms' environmental management practices. In general, emerging economies have poorer institutional controls towards the protection of natural environment, and at the same time higher tolerance towards pollution, aspects that favor the exploitative behavior of firms (Child \& Tsai, 2005; Christmann \& Taylor, 2001). Under such circumstances, those firms with environmentally exploitive behavior will face lower costs and weak regulatory sanctions against their polluting practices (Child \& Tsai, 2005).

Another important aspect to be considered at country level concerns factor markets (Wan \& Hoskisson, 2003). Factors are used to produce goods in transformational activities. The natural environment composes a strong part of a country endowed factor market and is a source of resources for firms (Wan \& Hoskisson, 2003). Natural resources play an important part in the industrialization process of emerging economies, and firms have developed competitive exportation strategies based on their access to natural resources or low-cost labor (Cuervo-Cazurra, 2008).

In Brazil, recent growth opportunities have been characterized by the focus on the exploration of factor markets (Wan, 2005), more specifically endowed factors derived from the natural environment. While the recent economic growth has been factor driven, for instance in the case of the expansion of agribusiness and extractive industries, the institutional framework has not advanced as much (Hoskisson et al., 2013; Rodrigues, 2013; Wan, 2005). In terms of environmental protection, Brazilian legislation provides for legal sanctions against polluters, however there is limited enforcement capacity (Brito \& Barreto, 2006).

Thus, in times of economic growth more pressure is exerted on the exploitation of natural resources and on polluting activities. At this point, both formal and informal constraints should regulate environmental practices; however institutional voids might allow polluting firms to continue producing without legal or market sanctions. 


\section{Environmental Management}

Environmental demands are grounded in the acknowledgement that firms provoke undesired impacts upon society in the course of their economic activities, the so called negative externalities. The quest for a balanced model of social-environmental-economic capital encompasses the whole society, both public and private agents, to take part in solutions and reduce the overall negative impact. The indispensable involvement of the private sector is based on the recognition that governments cannot address all potential externalities. Therefore, firms are expected to improve environmental management practices (also called environmental management systems), in changing production technology to diminish the usage of natural resources, to reduce waste and polluting outputs, as well as to increase recycling (Hart, 1995; Shrivastava, 1995). These practices include equipment, methods and procedures that aim at minimizing environmental impacts.

The institutional context has strong influence over the development of environmental management strategies (Hoffman, 2001). The drivers of environmental practices have been studied from different perspectives, such as market influences from customers, competitors, investors, suppliers, among others, and influences from other institutional agents such as governments, associations or industry groups (Delmas \& Toffel, 2004; Hoffman, 2001). In addition to external drivers, internal drivers include corporate values, employee pressure and management goals (Bansal \& Roth, 2000; Buysse \& Verbeke, 2003; Sharma \& Henriques, 2005). While both internal and external drivers are relevant, the focus of this study is on the influence of external drivers, considering their impacts on firm legitimacy and competitiveness (López-Gamero et al., 2010; Oliver, 1991; Rugman \& Verbeke, 1998).

The adoption of environmental management initiatives follows different strategies and different objectives for firms (Darnall, Henriques, \& Sadorsky, 2010; Hart, 1995; Porter \& Linde, 1995). Some firms respond to environmental demands with proactive strategies and the development of practices and innovations beyond those required by law (Darnall et al., 2010; Hart, 1995). Proactive strategies involve the development of resources, capabilities and green competencies that cannot be easily imitated by the market and provide superior competitiveness for firms (Buysse \& Verbeke, 2003; Christmann, 2000; Darnall et al., 2010). On the other hand, some firms present reactive responses aimed at pure compliance with existing regulation and the development of end-of-pipe solutions and pollution control initiatives (Hart, 1995; Shrivastava, 1995). Such initiatives involve limited resources and are designed to manage liability risks and to reduce costs (Buysse \& Verbeke, 2003; Sharma \& Vredenburg, 1998).

Overall, environmental management also has the objective of securing business legitimacy (Bansal \& Roth, 2000; Westley \& Vredenburg, 1996). Legitimacy is based on the assumption that environmental strategies reduce firms' negative impacts. However, most studies do not analyze the effective implementation of environmental practices (Aravind \& Christmann, 2011). The process of decoupling, in other words, the separation between policy adoption and actual practice, raises concerns about the effectiveness of environmental management as a whole (Aravind \& Christmann, 2011; Crilly et al., 2012). By decoupling policy from practice a firm can adopt conflicting standards in response to external pressures, considering that it is difficult for stakeholders to monitor a firms' internal practices (Christmann \& Taylor, 2001). The decoupling process is aimed at managing inconsistent demands, avoiding monitoring and mitigating conflicts with stakeholders (Crilly et al., 2012; J. W. Meyer \& Rowan, 1977). Occasionally, decoupling is seen as an intentional response of corporations to environmental demands; however it can also be the effect of a situation with complex and inconsistent demands (Crilly et al., 2012). It is also seen as a consequence of weak institutional contexts of emerging economies with low embeddedness and low internalization of laws (Rodrigues, 2013). In the analysis of environmental management, decoupling implies that the adoption of rules and standards cannot be considered as actual changes in daily practices. 
Many of the theoretical models about environmental management practices have been contextualized in developed countries (Buysse \& Verbeke, 2003; Delmas \& Toffel, 2004; Sharma \& Henriques, 2005), in which institutional frameworks and environmental performance differs from those of emerging economies (Hoskisson et al., 2000). In terms of environmental performance, Figure 1 illustrates the indexes of countries from emerging economies as opposed to some of the developed countries that have been studied. The environmental performance at a country level supports the notion that environmental management is not fully comparable across countries (Christmann \& Taylor, 2001).

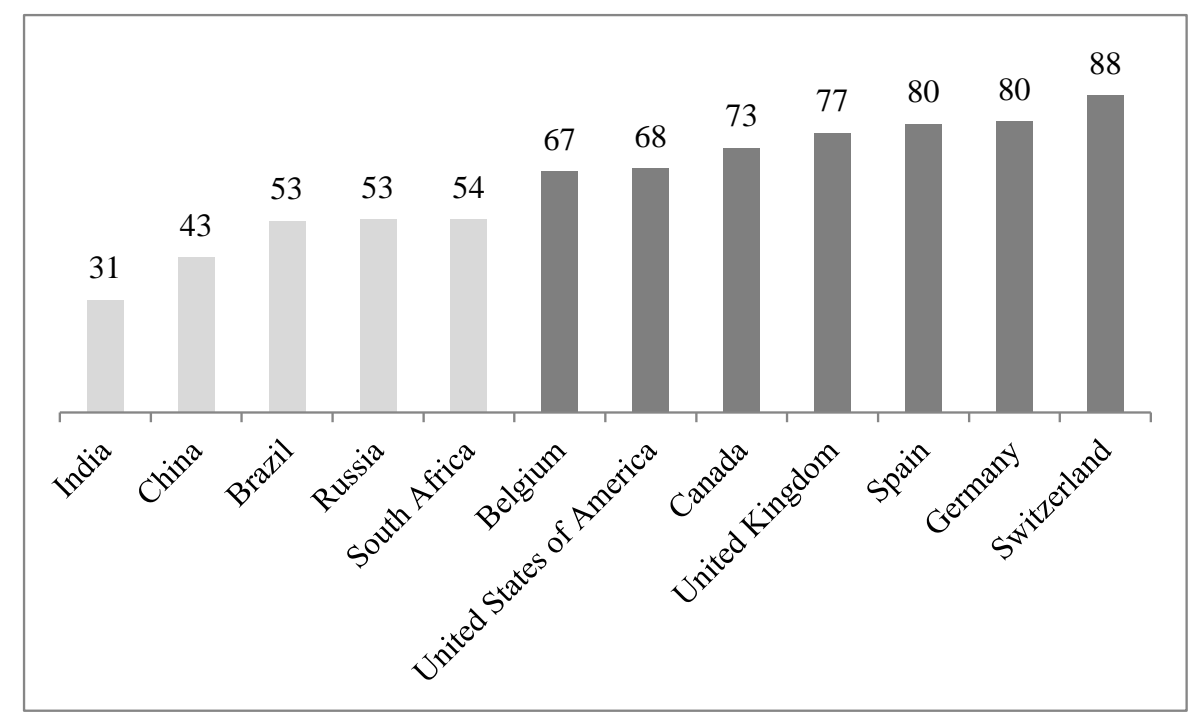

Figure 1. Environmental Performance Index (2014 EPI) ${ }^{(1)}$

Source: Based on Hsu, A., Emerson, J., Levy, M., Sherbinin, A. de, Johnson, L., Malik, O., Schwartz, J., \& Jaiteh, M. (2014). The 2014 environmental performance index. New Haven, CT: Yale Center for Environmental Law \& Policy. Retrieved from www.epi.yale.edu

Considering that the level of responsiveness to environmental drivers varies between firms and that results vary in terms of effectiveness, we build our hypotheses on how regulation, stakeholders, and voluntary norms exert influence over the environmental management practices of firms in the Brazilian context.

\section{Environmental regulation}

Environmental regulation, as a set of formal rules, comprises the standards imposed by the government to limit polluting activities and to establish penalties, fines and legal cost to noncompliance (Bansal \& Roth, 2000; Delmas \& Toffel, 2004; Rugman \& Verbeke, 1998). There are different regulation instruments, such as command and control and market-based instruments (taxes and subsidies) (Barbieri, 2007). In this study we focus on command and control instruments as they are comparable across the different federal states. As a mandatory stakeholder, the government is responsible for firms' formal license to operate and it provides the necessary legitimacy to businesses (Christmann, 2004; Delmas \& Toffel, 2008; Henriques \& Sadorsky, 1996; Walker; Di Sisto, \& McBain, 2008).

The compliance with regulation represents the basic phase of engagement in environmental management (Oliver, 1991). The environmental regulation provides equal conditions for all players and balances competitive forces upon which firms can gauge higher standards of operational change (Porter \& Linde, 1995). Firms with a pure pollution prevention strategy are primarily concerned with the compliance with environmental regulation (Buysse \& Verbeke, 2003). In general, the sheer adoption of a compliance strategy configures a reactive environmental strategy in which firms are not looking for competitive advantage (Rugman \& Verbeke, 1998). 
Environmental regulation primarily aims at reducing externalities. Command and control instruments tend to raise the operating costs in the first moments after their implementation (Rugman $\&$ Verbeke, 1998). Considering this, firms might decide to operate in the context of lax environmental regulation and low enforcement, such as the context of emerging markets. However, there are noncompliance sanctions and polluters assume the risk of being caught, which varies across countries. In the last decades, emerging countries have improved the controlling systems over polluting practices, narrowing the regulatory gap between them and developed countries (K. E. Meyer, 2004).

In terms of effectiveness, coercive regulation, usually comprised of command and control instruments, is supposed to improve environmental management practices. A study about Brazil's industrial sector indicated that regulator's sanctions and demands were the most influential factor in firms' environmental performance (Seroa da Motta, 2006) Thus, we can expect that regulation is positively related to the improvement of environmental management practices.

H1: Environmental regulation, focused on command and control instruments, have a positive influence on the environmental management practices of firms.

\section{Voluntary norms}

Voluntary norms are self-regulation strategies that go beyond compliance. In the literature there is a wide range of terminologies to indicate such strategies: voluntary environmental practices/initiatives (Christmann 2004; Sharma \& Vredenburg, 1998); voluntary environmental standards (Delmas \& Montiel, 2008; Walker et al., 2008); and voluntary norms ${ }^{(2)}$ (Barbieri, 2007; López-Gamero et al., 2010).

The emergence of voluntary norms such as the UN Global Compact, the ISO 14001 (International Environmental Management System Standard), and the GRI (Global Reporting Initiative) has offered guidelines for social and environmental management (Christmann \& Taylor, 2001; Delmas \& Montes-Sancho, 2011; Sharma, 2000). The adoption of environmental standards may be questioned in the initial phase, but, over time, it turns into a normative pressure towards an isomorphic process of adoption of such standards (Delmas \& Montes-Sancho, 2011). As selfregulation practices, these standards have been gradually institutionalized in the business environment and turned into a rule-like process.

In the adoption of voluntary norms, the main objective of firms is the search for legitimacy and competitiveness (Delmas \& Montes-Sancho, 2011). In the context of international trade, the adoption of voluntary norms closes the gap left by the weaknesses of local environmental regulation (Christmann \& Taylor, 2001). For this reason, export oriented firms are called to adopt environmental standards as a means to reach international markets (Prakash \& Potoski, 2006; Rugman \& Verbeke, 1998).

However, the effectiveness of voluntary norms may not be straightforward. Some firms obtain certification for environmental standards without fully complying with the prescribed practices (Aravind \& Christmann, 2011; Christmann \& Taylor, 2001). The decoupling raises concerns about the effectiveness of environmental standards, as they do not differentiate the quality of implementation. The variance in the process of auditing combined with lack of performance requirements provides an opportunity for superficial commitment to environmental management (Aravind \& Christmann, 2011; Buysse \& Verbeke, 2003).

Exploratory studies in Brazil have identified different profiles of environmental management among ISO 14001 certified firms (Gavronski et al., 2012; Jabbour et al., 2012). In general, the adoption of environmental standards is often considered a proactive environmental strategy that goes beyond compliance and has positive impacts on environmental management (Delmas \& Toffel, 2008; Gavronski, Ferrer, \& Paiva, 2008). Therefore, we formulate our second hypothesis: 
H2: The adoption of the voluntary norms has a positive influence on the environmental management practices of firms.

\section{Stakeholders' demand}

The importance of stakeholders in the achievement of a firm's objective is broadly recognized (Freeman, Wicks, \& Parmar, 2004). The definition of stakeholder itself - as those that affect or are affected by the firm (Freeman, 1984) - implies their importance in business strategy. Resources are developed in the complexity of interaction between the firm and its partners creating value in complementarity (Adegbesan, 2009; Sharma \& Henriques, 2005). In light of this, stakeholder pressure exerts important influence towards the implementation of environmental strategies and contributes to the development of resources (Hart \& Sharma, 2004; Porter \& Kramer, 2011).

The power of stakeholders is not evenly distributed; the firm's response to each group depends on the level of the firm's dependency and the stakeholder legitimacy (Eesley \& Lenox, 2006; Frooman, 1999). Firms depend on customers, and studies have demonstrated the influence of the customersupplier relationship in the implementation of environmental management practices (Darnall et al., 2010; Sharma \& Henriques, 2005). Competitors also exert strong influence over firms; they shape market practices and induce proactive environmental behavior (Delmas \& Toffel, 2008). Among societal stakeholders, local communities, environmental organizations and industry associations also contribute to the development of environmental practices (Darnall et al., 2010; Sharma \& Henriques, 2005). Positive interaction with stakeholders is associated with proactive environmental strategies.

There is not a unique shared view about environmental issues among stakeholders. The variances of views encompass different interests in the relationships with the firm (Crilly et al., 2012; Delmas \& Toffel, 2008). Organizations also respond differently to the same environmental demands (Delmas \& Toffel, 2008). Moreover, not all external stakeholders have knowledge about the practices inside firms, favoring the process of decoupling (Crilly et al., 2012). In the context of poorer institutional controls, stakeholder pressure may not offer clear sanctions and therefore may not always be effective in emerging economies

Recent studies have demonstrated positive influence of customers and the competitive environment on firms' practices in emerging economies (Abreu, Castro, Soares, \& Silva, 2012; Reimann, Ehrgott, Kaufmann, \& Carter, 2012). Assuming that the positive influence can be extended to environmental practices, we hypothesize the effect of customers, competitors and environmental organizations on environmental management practices as follows:

H3: Stakeholder pressure has a positive influence on the environmental management practices of firms.

The relevance of environmental drivers is contingent on factors such as the size of the firm, exposure to international markets and industry sector (González-Benito \& González-Benito, 2006; Reimann et al., 2012). Larger firms usually have higher public exposure and more resources to invest in environmental management (González-Benito \& González-Benito, 2006). International trade intensity also influences environmental management (Christmann \& Taylor, 2001; Muller \& Kolk, 2010). Institutional pressure also differs by industry, because of the nature of operations and the exposure to public awareness. Thus, analysis of the influence of institutional drivers upon environmental management practices must consider the influence of these factors. 


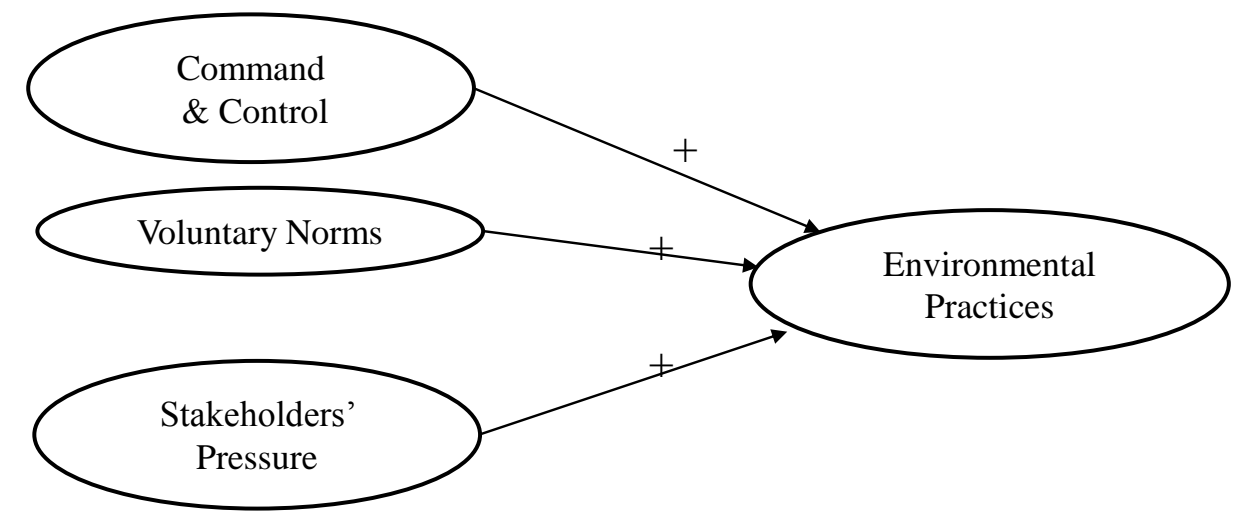

Figure 2. Hypothesized Model

\section{Methodology}

\section{Data and sample}

Data for this study was collected in a survey of firms located in two states of Brazil (Rio de Janeiro [RJ] and Rio Grande do Sul [RS]) during 2011. The sample is concentrated in manufacturing industry companies (Section C of Brazilian Classification [CNAE]). Manufacturing industry activities have strong environmental impacts and are subject to different types of institutional pressure. To ensure comparability, the survey was restricted to firms with more than 100 employees, which make up the universe of medium and large firms ${ }^{(3)}$.

The surveyed sample was extracted from two databases provided by the industry association of each state (FIERJ and FIERGS) with the companies' contacts. After an initial telephone contact, we collected the electronic address of environmental managers and sent the survey to 1027 firms (288 in Rio de Janeiro and 739 in Rio Grande do Sul). Environmental managers were asked to respond to a survey about their perception regarding the level of external pressure influence, as well as the environmental management practices implemented in each company. The key informants held responsibility for the company's environmental management and were 40 years old on average.

The survey delivery was followed by active calls resulting in 178 responses. The overall response rate of $17 \%$ was unevenly distributed between the two states (37\% in Rio de Janeiro and 10\% in Rio Grande do Sul). The survey response rate is compatible to that of other studies conducted with Brazilian companies (Gavronski et al., 2012; Jabbour, 2010). To access the response bias, we compared early responses to late ones, having found no significant difference between the groups ( $>0.05)$. We also compared the responses from the two federal states having found no significant disparity between them.

After a list wise elimination of respondents with incomplete information, the remaining 150 valid responses were analyzed. This sample included firms from 21 sub-industries under the manufacturing division. The literature suggests a minimum of 100 cases as a sample threshold, depending on the number of free parameters (Hair, Anderson, Tatham, \& Black, 2005). Given the low complexity of the proposed model and the number of parameters estimated, the sample size was considered adequate (Kline, 2005; MacCallum, Browne, \& Sugawara, 1996).

\section{Variables and measures}

The measurement model was developed in the adaptation of tested scales to the Brazilian context. The scales were translated and further evaluated by experts (academics and practitioners) in the area of sustainability and environmental management. The suggested changes were tested and 
incorporated into the applied survey. Out of the four constructs or our model, three were adapted from a study with Spanish firms (López-Gamero et al., 2010) and one was adapted from a research with Chinese firms (Cordeiro, Zhu, \& Sarkis, 2009). The complete scale is reported in Appendix with the results for the principal component analysis.

In the scales of command and control and voluntary norms managers were asked, on a 1-5 likert scale, about the extent of their agreement with the arguments, from strongly agree to strongly disagree (López-Gamero et al., 2010). Regarding the stakeholders' influence, managers were asked, on a 1-5 likert scale, about the importance of pressure perceived by the company from not at all important to extremely important (Cordeiro et al., 2009).

In the complete absence of indicators about environmental practices, we also used the managers' perceptions about the practices developed by the firms (López-Gamero et al., 2010). The measurement indicators include both managerial practices and technical practices to account for all internal environmental management procedures. Managers were asked to evaluate the implemented environmental practices from 1 (they had not addressed the issue) to 5 (they were leaders in the practice in their industry) (López-Gamero et al., 2010). Both managerial practices and technical practices constitute one construct of environmental management, and this was confirmed in the principal component analysis (see Appendix).

We also tested the effects of control variables that could potentially influence the relationships modeled (González-Benito \& González-Benito, 2006; Reimann et al., 2012). The influence of firm size was controlled with a variable about number of employees. The relevance of industry group was tested with a dummy variable. Finally, we included a dummy variable about firm exporting activities, to incorporate the potential influence of international customers.

Because of the non-existence of alternative data sources, both dependent and independent variables were measured in the same questionnaire. Therefore, we took measures to reduce and analyze the influence of common method bias (Podsakoff, MacKenzie, Lee, \& Podsakoff, 2003). In terms of procedural remedies, in the design of the questionnaire we used reversed coded items in some scales. We also placed stakeholders' scales at the end of the questionnaire to limit the contextual cues. In terms of statistical remedies, we applied Harman's single factor test. Harman's test was conducted, by including all the variables in the study into an unrotated factor analysis, to verify if the majority of the variance could be accounted for by one general factor. The result of the factor analysis for all 15 items revealed four factors, none of them explaining more that 30 percent of the variance extracted. These results minimize the concerns about the common method biases in the study.

\section{Results}

\section{Measurement model}

The hypotheses about the influence of different institutional drivers on environmental management practices were tested using a Structural Equation Modeling estimated via maximum likelihood, with AMOS software version 16.0 (Byrne, 2010). The method estimates the relations between the constructs (latent variables) and their indicators (observable variables) simultaneously; and has been increasingly employed in organization studies (Roberts, Thatcher, \& Grover, 2010; Shook, Ketchen, Hult, \& Kacmar, 2004).

The measurement model was analyzed with confirmatory factor analysis (CFA). In the process scale purification some items were eliminated considering their factor loading and the nomological validity of the constructs (see Appendix) (Kline, 2005; Schumacker \& Lomax, 2004). Results for reliability and validity tests are reported in Table 1. 
Table 1

Correlations, Descriptive Statistics, Reliability and Validity Tests

\begin{tabular}{lccccccc}
\hline & CC & Vol & Stk & MP & TP & $\begin{array}{c}\text { Composite } \\
\text { Reliability }\end{array}$ & AVE \\
\hline CC - Command and control & 1 & & & & & 0.72 & $47 \%$ \\
Vol - Voluntary norms & $0.321^{* *}$ & 1 & & & & 0.78 & $54 \%$ \\
Stk - Stakeholders & $0.219^{* *}$ & $0.190^{*}$ & 1 & & & 0.76 & $52 \%$ \\
MP - Managerial practices & $0.282^{* *}$ & $0.184^{*}$ & $0.430^{* *}$ & 1 & & 0.74 & $66 \%$ \\
TP - Technical practices & $0.295^{* *}$ & 0.040 & $0.374^{* *}$ & $0.548^{* *}$ & 1 & 0.87 & $76 \%$ \\
Mean & 4.367 & 4.556 & 2.576 & 3.093 & 3.156 & & \\
Standard deviation & 0.614 & 0.556 & 1.207 & 1.020 & 0.905 & & \\
\hline
\end{tabular}

Note. $* \mathrm{p}<0.05 . * * \mathrm{p}<0.001$.

The test of composite reliability was calculated with the standardized regression loadings and errors, with all loadings being above the 0.7 recommended level (Fornell \& Larcker, 1981). We also calculated Cronbach's alpha coefficient (see Appendix) and the two tests indicate good reliability of the scale. The convergent validity of the constructs was analyzed in the average variance extracted (AVE) in each variable. The results are satisfactory for most of the constructs, with AVE above 50\%, with exception of the variable of command and control that was on the borderline of acceptance in the model. Discriminant validity was evaluated and confirmed in the contrast of the AVE with constructs correlations (Fornell \& Larcker, 1981). For all constructs, the square root of AVE of each construct exceeded the correlation coefficients, demonstrating good discriminant validity and eliminating the potential issues with multicollinearity.

Additionally, we examined the fit indexes of the measurement models. In terms of global fit measures, we used the $\chi^{2}$ index (Kline, 2005). In terms of the parsimony fit index, the RMSEA (Root Mean Square Error of Approximation) estimated the discrepancy between the original and reproduced covariance matrices and values below 0.05 indicate a good fit, whereas values over 0.1 indicates problems with the model (Browne \& Cudeck, 1993). In the analysis of incremental indexes, the Comparative Fit Index (CFI) and the Tucker-Lewis Index (TLI) should be close to 1 (Byrne, 2010; Schumacker \& Lomax, 2004). The results of $\chi^{2}(111.1 ; \mathrm{df}=80$; pvalue 0.012), RMSEA $(0.051)$ and CFI (0.959) indicated a good parsimony and incremental indexes for the measurement model.

\section{Structural model and hypotheses testing}

After analysis of the measurement model, we proceeded to the structural model and to testing the hypotheses. In the structural model we included the influence of the control variables and tested for robustness, comparing the theoretical model with the collected data (Kline, 2005; Schumacker \& Lomax, 2004).

In terms of fit, the model presented good parsimony fit (RMSEA $=0.04$; range 0.018 to 0.063 ; pclose $=0.683)$ and $\left(\chi^{2}=147.7, \mathrm{df}=115, \mathrm{p}=0.021\right)$. In terms of incremental index, the CFI $(0.958)$ and the TLI (0.944) indicate good fit of the model.

As per the hypotheses test, the results provided support to H1 $(\beta=0.298$; pvalue $=0.02)$ confirming the positive influence of regulation over environmental management practices. On the other hand, the influence of voluntary norms over environmental management practices could not be confirmed $\mathrm{H} 2(\beta=-0.027$; pvalue $=0.8)$. As per $\mathrm{H} 3$, the power stakeholders have over the implementation of environmental management practices was confirmed $(\beta=0.523$, pvalue $=0)$. The control variables, size, industry and exporter did not yield significant results $(\mathrm{p}<0.05)$. Overall, the 
model indicates that firms' responsiveness to environmental pressure varies across the different institutional drivers (Figure 3).

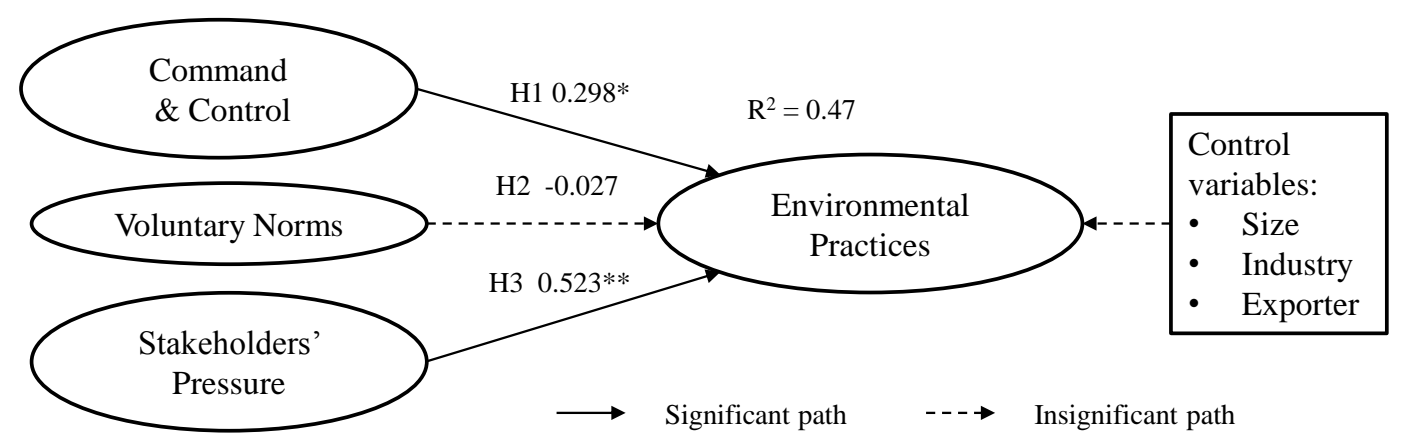

Figure 3. Structural Model and Standardized Regression Coefficients $* \mathrm{p}<0.05 . * * \mathrm{p}<0.001$.

\section{Discussion and Conclusion}

How effective are environmental drivers in promoting change inside firms? From formal rules to informal norms, the set of environmental drivers offers guidelines for the adoption of environmental practices. However, environmental drivers are not perceived homogeneously by firms in different contexts and this variance is also reflected in the levels of their responsiveness (Christmann, 2004; Clarkson et al., 2011). This issue is even more relevant considering that the symbolic adoption of environmental practices may be disconnected from its actual implementation (King, Lenox, \& Terlaak, 2005).

Our study advances in this discussion as our data shows that not all drivers produce the desired effect on environmental practices, even if such drivers are perceived as a market opportunity by firms. The implementation of environmental practices is normally a middle step between institutional drivers and competitive results; however the relationship is not always straight forward. This phenomenon is based on decoupling and on the fact that legitimation is not necessarily related to the implementation of practices (J. W. Meyer \& Rowan, 1977). This type of study is particularly relevant in the context of emerging economies in which there is higher tolerance of non-compliant behavior (Child \& Tsai, 2005; Christmann \& Taylor, 2001). In testing the most relevant external drivers, command and control, voluntary norms and stakeholder pressure, we covered the broad spectrum of institutional forces acting on firms.

Our results demonstrate that the positive perception of environmental drivers may not be associated with changes in practices. Even though managers recognize voluntary norms instrumental to the improvement of public image, the hypothesis about voluntary norms' positive influence on environmental practices was not confirmed. This demonstrates the need for further investigation into the effectiveness of self-regulation strategies. Voluntary norms, such as the case of ISO 14001 and other environmental standards, do not differentiate between the levels of implementation of environmental norms; thus, the need for a more rigorous process of auditing these initiatives (Aravind \& Christmann, 2011; Christmann \& Taylor, 2001; King et al., 2005). Moreover, some environmental standards may serve as window-dressing to firms with no commitment to environmental protection (Buysse \& Verbeke, 2003).

This finding also evidences the shortcomings of the analysis of voluntary norms, such as ISO 14001 certification, as proxy for proactive environmental strategy. Contrary to the idea of proactive strategy, those initiatives might not lead towards the improvement of the natural environment (Darnall et al., 2010; Hart, 1995). The process of decoupling has two implications to firms. On one hand, it 
provides access to market (Delmas \& Montes-Sancho, 2011). On the other hand, it does not involve changes in the operations and internalization of costs. Even though it might seem attractive, this choice also has the shortcomings, as it would not lead to the development of competitive resources for the firm (Jabbour et al., 2012).

When it comes to regulation, command and control instruments demonstrated positive influence over environmental practices. Governmental regulation was recognized as promoting higher standards for the development of products, even though it is supposed to provide the baseline for environmental management. This result illustrates the non-uniformity of the perception about legislation across different institutional contexts. Studies about environmental legislation in Europe do not endorse the idea of a positive influence of command and control over environmental management (López-Gamero et al., 2010; Smith \& Crotty, 2008). However, in the context of institutional voids, the formal rules are important drivers for investment decisions, reducing uncertainty in emerging economies (Peng, 2002). Our survey reveals that managers perceive that regulation has become stricter, confirming the tendencies of emerging economies to narrow the regulatory gap (K. E. Meyer, 2004). Regulation compliance is not recognized as a proactive response; however, it encouraged firms to move further in process of practices implementation. More rigorous environmental policies reduce uncertainty and may stimulate firms to invest in the development of initiatives beyond mere compliance (Christmann, 2004).

The positive pressure stakeholders, customers, competitors and environmental organizations have was also confirmed. In comparison with command and control, stakeholder pressure demonstrated a stronger influence over environmental practices. This finding is aligned with other studies and reinforces the relationship between stakeholder pressure and proactive strategies (Darnall et al., 2010; Sharma \& Henriques, 2005). The strength of stakeholder relationships relies on the interdependence of firms on the development of resources and capabilities (Buysse \& Verbeke, 2003). As firms rely on partners to create value, the relative importance of environmental management for one firm can spill over to business partners in the value chain (Seuring \& Müller, 2008). Additionally, the value attributed to proactive environmental management may influence firms' market values (Dowell et al., 2000).

The confirmation of stakeholders' importance in the context of an emerging economy does not exclude the need to understand the specificities of each context. As other studies have demonstrated, the importance of business partners can be contingent on country specificities and on stakeholder interactions (Abreu et al., 2012; Bandeira-de-Mello, Marcon, \& Alberton, 2011).

Apart from the theoretical implications, this study offers insights into environmental organizations and public policies. In terms of environmental protection, the acknowledgement that stakeholders induce the improvement of environmental practices is an indication that actions towards the value chain can be rewarding. That is, NGOs and policymakers may target key players in a value chain to achieve a broader range of firms, suppliers and competitors. In terms of environmental practices, the recognition that policies might not actually be implemented calls for better auditing of environmental accreditation processes. Finally, even though regulation is not always welcomed by firms, the study demonstrates its importance in the environmental management.

Our study presents limitations, some already addressed in the methodology section, and some opportunities for future studies. In terms of sample representation, we suggest the expansion of the investigation to other industries and regions of Brazil. In general, there is still a strong need for studies outside the context of developed countries. In terms of drivers, we acknowledge that there are more drivers that influence environmental behavior. Thus we encourage the investigation of more detailed drivers in the context of emerging economies, comparing the effectiveness of internal drivers to external drivers, for instance. In terms of environmental practices, it would be important to have access to an objective measure of environmental performance to check the results. We also suggest the examination of the effectiveness specific environmental standards such as ISO 14001 and Forest Stewardship Council (FSC), often regarded as proxy for environmental performance. The recognition of the force and limitations of environmental drivers is a first step towards a deeper investigation. 


\section{Notes}

\footnotetext{
${ }^{1}$ The Environmental Performance Index (EPI) is a global scorecard that congregates the major environmental issues at a country level, such as water resources, agriculture, forest protection, fishery, biodiversity and habitat, climate and energy, health impacts, air quality and water and sanitation.

${ }^{2}$ This nomenclature has been adopted to align our study with that of López-Gamero, Molina-Azorín, and Claver-Cortés (2010) which provided the scales for the variable.

${ }^{3}$ As per Departamento Intersindical de Estatística e Estudos Socioeconômicos (DIEESE) classification.
}

\section{References}

Abreu, M. C. S. de, Castro, F. de, Soares, F. A. de, \& Silva, J. C. L. da, Filho (2012). A comparative understanding of corporate social responsibility of textile firms in Brazil and China. Journal of Cleaner Production, 20(1), 119-126. doi: 10.1016/j.jclepro.2011.08.010

Adegbesan, J. A. (2009). On the origins of competitive advantage: strategic factor markets and heterogeneous resource complementarity. Academy of Management Review, 34(3), 463-475. doi: 10.5465/AMR.2009.40632465

Aravind, D., \& Christmann, P. (2011). Decoupling of standard implementation from certification: does quality of ISO 14001 implementation affect facilities' environmental performance? Business Ethics Quarterly, 21(1), 73-102. doi: 10.1017/S1052150X00010277

Bandeira-de-Mello, R., Marcon, R., \& Alberton, A. (2011). Performance effects of stakeholder interaction in emerging economies: evidence from Brazil. Brazilian Administration Review, 8(3), 329-350. Retrieved from http://www.scielo.br/pdf/bar/v8n3/a07v8n3.pdf. doi: 10.1590/S180776922011000300007

Bansal, P., \& Roth, K. (2000). Why companies go green: a model of ecological responsiveness. Academy of Management Journal, 43(4), 717-736. doi: 10.2307/1556363

Barbieri, J. C. (2007). Gestão ambiental empresarial conceitos, modelos e instrumentos. São Paulo: Saraiva.

Brito, B., \& Barreto, P. (2006). Enforcement against illegal logging in the Brazilian Amazon. Retrieved from http://www.imazon.org.br/publicacoes/publicacao.asp?id=478

Browne, M. W., \& Cudeck, R. (1993). Alternative ways of assessing model fit. In K. A. Bollen \& J. S. Long (Eds.), Testing structural equation models (Vol. 154, pp. 136-162). Newbury Park, CA: Sage Focus Editions.

Buysse, K., \& Verbeke, A. (2003). Proactive environmental strategies: a stakeholder management perspective. Strategic Management Journal, 24(5), 453. doi: 10.1002/smj.299

Byrne, B. M. (2010). Structural equation modeling with AMOS: basic concepts, applications, and programming (2nd ed.). New York: Routledge.

Carney, M., Gedajlovic, E. R., Heugens, P. P. M. A. R., Van Essen, M., \& Van Oosterhout, J. (2011). Business group affiliation, performance, context, and strategy: a meta-analysis. Academy of Management Journal, 54(3), 437-460. doi: 10.5465/amj.2011.61967812

Child, J., \& Tsai, T. (2005). The dynamic between firms' environmental strategies and institutional constraints in emerging economies: evidence from China and Taiwan. Journal of Management Studies, 42(1), 95-125. doi: 10.1111/j.1467-6486.2005.00490.x 
Christmann, P. (2000). Effects of "best practices" of environmental management on cost advantage: the role of complementary assets. Academy of Management Journal, 43(4), 663-680. doi: $10.2307 / 1556360$

Christmann, P. (2004). Multinational companies and the natural environment: determinants of global environmental policy standardization. Academy of Management Journal, 47(5), 747-760.

Christmann, P., \& Taylor, G. (2001). Globalization and the environment: determinants of firm selfregulation in China. Journal of International Business Studies, 32(3), 439-458. doi: 10.1057/palgrave.jibs.8490976

Clarkson, P. M., Li, Y., Richardson, G. D., \& Vasvari, F. P. (2011). Does it really pay to be green? Determinants and consequences of proactive environmental strategies. Journal of Accounting \& Public Policy, 30(2), 122-144. doi: 10.1016/j.jaccpubpol.2010.09.013

Cordeiro, J. J., Zhu, Q., \& Sarkis, J. (2009, August). International and domestic pressures and chinese organizational responses to greening. Proceedings of the Academy of Management Annual Conference, Chicago, Illinois, USA, 69.

Crilly, D., Zollo, M., \& Hansen, M. T. (2012). Faking it or muddling through? Understanding decoupling in response to stakeholder pressures. Academy of Management Journal, 55(6), 14291448. doi: $10.5465 / \mathrm{amj} .2010 .0697$

Cuervo-Cazurra, A. (2008). The multinationalization of developing country MNEs: the case of multilatinas. Journal of International Management, 14(2), 138-154. doi: 10.1016/j.intman.2007.09.001

Darnall, N., Henriques, I., \& Sadorsky, P. (2010). Adopting proactive environmental strategy: the influence of stakeholders and firm size. Journal of Management Studies, 47(6), 1072-1094. doi: 10.1111/j.1467-6486.2009.00873.x

Delmas, M. A., \& Montes-Sancho, I. M. J. (2011). An institutional perspective on the diffusion of international management system standards: the case of the environmental management standard ISO 14001. Business Ethics Quarterly, 21(1), 103-132. doi: 10.5840/beq20112115

Delmas, M. A., \& Toffel, M. W. (2004). Stakeholders and environmental management practices: an institutional framework. Business Strategy \& the Environment, 13(4), 209-222. doi: $10.1002 /$ bse.409

Delmas, M. A., \& Toffel, M. W. (2008). Organizational responses to environmental demands: opening the black box. Strategic Management Journal, 29(10), 1027-1055. doi: 10.1002/smj.701

DiMaggio, P., \& Powell, W. W. (1983). The iron cage revisited: institutional isomorphism and collective rationality in organizational fields. American Sociological Review, 48(2), 147-160.

Dowell, G., Hart, S., \& Yeung, B. (2000). Do corporate global environmental standards create or destroy market value? Management Science, 46(8), 1059-1074. doi: 10.1287/mnsc.46.8.1059.12030

Eesley, C., \& Lenox, M. J. (2006). Firm responses to secondary stakeholder action. Strategic Management Journal, 27(8), 765-781. doi: 10.1002/smj.536

Fornell, C., \& Larcker, D. F. (1981). Evaluating structural equation models with unobservable variables and measurement error. Journal of Marketing Research, 18(1), 39-50.

Freeman, R. E. (1984). Strategic management: a stakeholder approach. Boston: Pitman. 
Freeman, R. E., Wicks, A. C., \& Parmar, B. (2004). Stakeholder theory and "the corporate objective revisited". Organization Science, 15(3), 364-369. doi: 10.1287/orsc.1040.0066

Frooman, J. (1999). Stakeholder influence strategies. Academy of Management Review, 24(2), 191205. doi: 10.5465/AMR.1999.1893928

Gavronski, I., Ferrer, G., \& Paiva, E. L. (2008). ISO 14001 certification in Brazil: motivations and benefits. Journal of Cleaner Production, 16(1), 87-94. doi: 10.1016/j.jclepro.2006.11.002

Gavronski, I., Paiva, E. L., Teixeira, R., \& Andrade, M. C. F. de (2012). ISO 14001 certified plants in Brazil-taxonomy and practices. Journal of Cleaner Production, 39, 32-41. doi: 10.1016/j.jclepro.2012.08.025

Goldszmidt, R. G. B., Brito, L. A. L., \& Vasconcelos, F. C. de (2011). Country effect on firm performance: a multilevel approach. Journal of Business Research, 64(3), 273-279. doi: 10.1016/j.jbusres.2009.11.012

González-Benito, J., \& González-Benito, Ó. (2006). A review of determinant factors of environmental proactivity. Business Strategy and the Environment, 15(2), 87-102. doi: 10.1002/bse.450

Hair, J. F., Anderson, R. E., Tatham, R. L., \& Black, W. C. (2005). Análise multivariada de dados (5a ed.). Porto Alegre: Bookman.

Hart, S. L. (1995). A natural-resource-based view of the firm. Academy of Management Review, 20(4), 986-1014. doi: 10.5465/AMR.1995.9512280033

Hart, S. L., \& Sharma, S. (2004). Engaging fringe stakeholders for competitive imagination. Academy of Management Executive, 18(1), 7-18. doi: 10.5465/ame.2004.12691227

Henriques, I., \& Sadorsky, P. (1996). The determinants of an environmentally responsive firm: an empirical approach. Journal of Environmental Economics and Management, 30(3), 381-395. doi: 10.1006/jeem.1996.0026

Hoffman, A. J. (2001). Linking organizational and field-level analyses: the diffusion of corporate environmental practice. Organization \& Environment, 14(2), 133-156. doi: $10.1177 / 1086026601142001$

Hoskisson, R. E., Eden, L., Lau, C. M., \& Wright, M. (2000). Strategy in emerging economies. Academy of Management Journal, 43(3), 249-267. doi: 10.2307/1556394

Hoskisson, R. E., Wright, M., Filatotchev, I., \& Peng, M. W. (2013). Emerging multinationals from mid-range economies: the influence of institutions and factor markets. Journal of Management Studies, 50(7), 1295-1321. doi: 10.1111/j.1467-6486.2012.01085.x

Hsu, A., Emerson, J., Levy, M., Sherbinin, A. de, Johnson, L., Malik, O., Schwartz, J., \& Jaiteh, M. (2014). The 2014 environmental performance index. New Haven, CT: Yale Center for Environmental Law \& Policy. Retrieved from www.epi.yale.edu

Jabbour, C. J. C. (2010). In the eye of the storm: exploring the introduction of environmental issues in the production function in Brazilian companies [Case Study]. International Journal of Production Research, 48(21), 6315-6339. doi: 10.1080/00207540802425401

Jabbour, C. J. C., Silva, E. M. da, Paiva, E. L., \& Almada Santos, F. C. (2012). Environmental management in Brazil: is it a completely competitive priority? Journal of Cleaner Production, 21(1), 11-22. doi: 10.1016/j.jclepro.2011.09.003 
King, A. A., Lenox, M. J., \& Terlaak, A. (2005). The strategic use of decentralized institutions: exploring certification with the ISO 14001 management standard. Academy of Management Journal, 48(6), 1091-1106. doi: 10.5465/AMJ.2005.19573111

Kline, R. B. (2005). Principles and practice of structural equation modeling (2nd ed.). New York: Guilford Press.

López-Gamero, M. D., Molina-Azorín, J. F., \& Claver-Cortés, E. (2010). The potential of environmental regulation to change managerial perception, environmental management, competitiveness and financial performance. Journal of Cleaner Production, 18(10/11), 963-974. doi: 10.1016/j.jclepro.2010.02.015

MacCallum, R. C., Browne, M. W., \& Sugawara, H. M. (1996). Power analysis and determination of sample size for covariance structure modeling. Psychological Methods, 1(2), 130-149. doi: 10.1037/1082-989X.1.2.130

Meyer, J. W., \& Rowan, B. (1977). Institutionalized organizations: formal organizations as myth and ceremony. American Journal of Sociology, 83(2), 340-363.

Meyer, K. E. (2004). Perspectives on multinational enterprises in emerging economies. Journal of International Business Studies, 35(4), 259-276. doi: 10.1057/palgrave.jibs.8400084

Muller, A., \& Kolk, A. (2010). Extrinsic and intrinsic drivers of corporate social performance: evidence from foreign and domestic firms in Mexico. Journal of Management Studies, 47(1), 126. doi: $10.1111 / \mathrm{j} .1467-6486.2009 .00855 . \mathrm{x}$

North, D. C. (1990). Institutions, institutional change and economic performance. New York: Cambridge University Press.

Oliver, C. (1991). Strategic responses to institutional processes. Academy of Management Review, 16(1), 145-179. doi: 10.5465/AMR.1991.4279002

Peng, M. W. (2002). Towards an institution-based view of business strategy. Asia Pacific Journal of Management, 19(2/3), 251-267. doi: 10.1023/A:1016291702714

Podsakoff, P. M., MacKenzie, S. B., Lee, J.-Y., \& Podsakoff, N. P. (2003). Common method biases in behavioral research: a critical review of the literature and recommended remedies. Journal of Applied Psychology, 88(5), 879-903. doi: 10.1037/0021-9010.88.5.879

Porter, M. E., \& Kramer, M. R. (2011). Creating shared value. Harvard Business Review, 89(1/2), 62-77.

Porter, M. E., \& Linde, C. van der (1995). Toward a new conception of the environmentcompetitiveness relationship. Journal of Economic Perspectives, 9(4), 97-118. doi: $10.1257 /$ jep.9.4.97

Prakash, A., \& Potoski, M. (2006). Racing to the bottom? Trade, environmental governance, and ISO 14001. American Journal of Political Science, 50(2), 350-364. doi: 10.1111/j.15405907.2006.00188.x

Reimann, F., Ehrgott, M., Kaufmann, L., \& Carter, C. R. (2012). Local stakeholders and local legitimacy: MNEs' social strategies in emerging economies. Journal of International Management, 18(1), 1-17. doi: 10.1016/j.intman.2011.06.002

Roberts, N., Thatcher, J. B., \& Grover, V. (2010). Advancing operations management theory using exploratory structural equation modelling techniques. International Journal of Production Research, 48(15), 4329-4353. doi: 10.1080/00207540902991682 
Rodrigues, S. B. (2013, June 13). Understanding the environments of emerging markets: the social costs of institutional voids. ERIM Farewell Address Series Research in Management. Retrieved from http://hdl.handle.net/1765/40429

Rugman, A. M., \& Verbeke, A. (1998). Corporate strategies and environmental regulations: an organizing framework. Strategic Management Journal, 19(4), 363-375. doi: 10.1002/(SICI)1097-0266(199804)19:4<363::AID-SMJ974>3.0.CO;2-H

Schumacker, R. E., \& Lomax, R. G. (2004). A beginner's guide to structural equation modeling (2nd ed.). Mahwah, N.J.: Lawrence Erlbaum Associates.

Seroa da Motta, R. (2006). Analyzing the environmental performance of the Brazilian industrial sector. Ecological Economics, 57(2), 269-281. doi: 10.1016/j.ecolecon.2005.04.008

Seuring, S., \& Müller, M. (2008). From a literature review to a conceptual framework for sustainable supply chain management. Journal of Cleaner Production, 16(15), 1699-1710. doi: 10.1016/j.jclepro.2008.04.020

Sharma, S. (2000). Managerial interpretations and organizational context as predictors of corporate choice of environmental strategy. Academy of Management Journal, 43(4), 681-697. doi: $10.2307 / 1556361$

Sharma, S., \& Henriques, I. (2005). Stakeholder influences on sustainability practices in the canadian forest products industry. Strategic Management Journal, 26(2), 159-180. doi: 10.1002/smj.439

Sharma, S., \& Vredenburg, H. (1998). Proactive corporate environmental strategy and the development of competitively valuable organizational capabilities. Strategic Management Journal, 19(8), 729-753. doi: 10.1002/(SICI)1097-0266(199808)19:8<729::AIDSMJ967>3.0.CO;2-4

Shook, C. L., Ketchen, D. J., Jr., Hult, G. T. M., \& Kacmar, K. M. (2004). An assessment of the use of structural equation modeling in strategic management research. Strategic Management Journal, 25(4), 397-404. doi: $10.1002 / \mathrm{smj} .385$

Shrivastava, P. (1995). Environmental technologies and competitive advantage. Strategic Management Journal, 16(S1), 183-200. doi: 10.1002/smj.4250160923

Smith, M., \& Crotty, J. (2008). Environmental regulation and innovation driving ecological design in the UK automotive industry. Business Strategy and the Environment, 17(6), 341-349. doi: $10.1002 / b s e .550$

Walker, H., Di Sisto, L., \& McBain, D. (2008). Drivers and barriers to environmental supply chain management practices: lessons from the public and private sectors. Journal of Purchasing and Supply Management, 14(1), 69-85. doi: 10.1016/j.pursup.2008.01.007

Wan, W. P. (2005). Country resource environments, firm capabilities, and corporate diversification strategies. Journal of Management Studies, 42(1), 161-182. doi: 10.1111/j.14676486.2005.00492.x

Wan, W. P., \& Hoskisson, R. E. (2003). Home country environments, corporate diversification strategies, and firm performance. Academy of Management Journal, 46(1), 27-45. doi: $10.2307 / 30040674$

Westley, F., \& Vredenburg, H. (1996). Sustainability and the corporation. Journal of Management Inquiry, 5(2), 104-119. doi: 10.1177/105649269652003 
Wright, M., Filatotchev, I., Hoskisson, R. E., \& Peng, M. W. (2005). Strategy research in emerging economies: challenging the conventional wisdom. Journal of Management Studies, 42(1), 1-33. doi: 10.1111/j.1467-6486.2005.00487.x

\section{Authors' Profiles}

Patricia Calicchio Berardi

Rua Doutor Álvaro Alvim, 123, Vila Mariana, 04018-010, São Paulo, SP, Brazil. E-mail address: patricia.berardi@espm.br

Renata Peregrino de Brito

OneAdvisory, Rua Otavio Correia, 273 -2, 22291-180, Rio de Janeiro, RJ, Brazil. E-mail address: renatap.brito@gmail.com 


\section{APPENDIX}

\section{Questionnaire Scale Items and Results from Confirmatory Factor Analysis}

Command and control

- establishes rigid restrictions for the adoption of new products and technological processes

- encourages the adoption of the best practices available

- has become too strict in recent years

- increases firm costs *

Eigenvalue of 1.9 explaining 64.3 percent of the variance. Alpha coefficient 0.72

Voluntary norms

- generates incentives to innovate, as it encourages the adoption of cleaner technology

- provides a better image of the firm

- represents a market opportunity for the firm

- are required by the market*

Eigenvalue of 2.05 explaining 68.5 percent of the variance. Alpha coefficient 0.76

Stakeholder Pressure: the extent of environmental pressure perceived

- from domestic customers

- from environmental organizations and professional entities

- from competitors

0.77

Eigenvalue of 2 explaining 67 percent of the variance. Alpha coefficient 0.75

Environmental Management - Managerial practices: the firm...

- removes barriers to environmental communications, including encouragement for employees to communicate directly with their managers or with other firm employees

- adapts or modifies the organizational structures to facilitate environmental management

- revises environmental and procedure manuals periodically

- employees have the environmental competencies required*

Environmental Management - Technical practices: The firm...

- focus on the lower consumption of resources

- develops energy efficient logistics

- has implemented cleaner production techniques in the last 5 years

- selects low-impact materials*

Eigenvalue of 3.36 explaining 56 percent of the variance. Alpha coefficient 0.84

Note. $\uparrow$ All Factor Loadings are significant $(\mathrm{p}<0.001)$.

* Item deleted for low factor loading. 